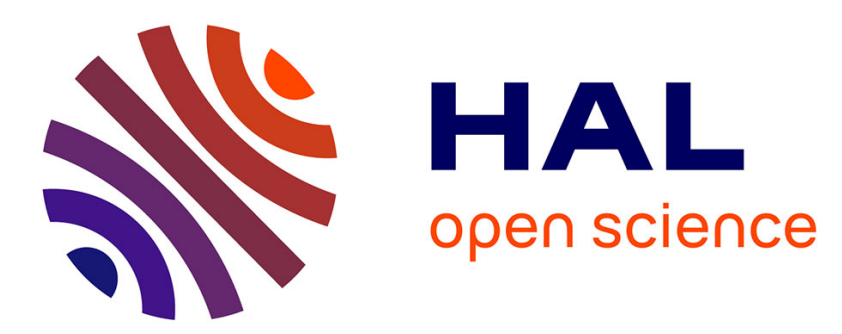

\title{
Iron complexation by phenolic ligands in seawater
}

Aridane G. Gonzalez, M. Isabel Cadena-Aizaga, Géraldine Sarthou, Melchor

Gonzalez-Davila, J.M. Santana-Casiano

\section{To cite this version:}

Aridane G. Gonzalez, M. Isabel Cadena-Aizaga, Géraldine Sarthou, Melchor Gonzalez-Davila, J.M. Santana-Casiano. Iron complexation by phenolic ligands in seawater. Chemical Geology, 2019, Cycles of trace elements and isotopes in the ocean - GEOTRACES and beyond, 511, pp.380-388. 10.1016/j.chemgeo.2018.10.017 . hal-02322486

\section{HAL Id: hal-02322486 https://hal.science/hal-02322486}

Submitted on 2 Jun 2020

HAL is a multi-disciplinary open access archive for the deposit and dissemination of scientific research documents, whether they are published or not. The documents may come from teaching and research institutions in France or abroad, or from public or private research centers.
L'archive ouverte pluridisciplinaire HAL, est destinée au dépôt et à la diffusion de documents scientifiques de niveau recherche, publiés ou non, émanant des établissements d'enseignement et de recherche français ou étrangers, des laboratoires publics ou privés. 
2 Aridane G. González ${ }^{1,2 *}$, M. Isabel Cadena-Aizaga ${ }^{2}$, Geraldine Sarthou ${ }^{1}$, Melchor

$5 \quad{ }^{1}$ CNRS, Université de Brest, IRD, Ifremer, UMR 6539 LEMAR, IUEM; Technopôle

6 Brest Iroise, Place Nicolas Copernic, F-29280 Plouzané, France

$7 \quad{ }^{2}$ Instituto de Oceanografía y Cambio Global, IOCAG. Universidad de Las Palmas de Gran

8 Canaria, ULPGC, Parque Científico Tecnológico de Taliarte, 35214, Telde. Spain.

$9 \quad *$ Corresponding author: aridane.gonzalez@ulpgc.es. Phone: +34 928454436 


\section{Abstract}

11 Iron is an essential micronutrient for phytoplankton and can limit primary production in

12 the ocean. Fe chemistry is highly controlled by its interaction with organic complexes ( $>$ 99\%). It is still unknown which organic compounds produced by cells have the ability to bind Fe. Within the pool of organic ligands, polyphenols are known to be exudated by marine diatoms and, in this study, the role of three polyphenols $(( \pm)-$ catechin, sinapic acid and gallic acid) was studied in terms of dissolved Fe complexation via kinetic and titration approaches, and also their role as a source of Fe(II) in seawater. The results demonstrated that these three polyphenols are weak $\mathrm{L}_{2}$-type Fe-binding ligands according to the conditional stability constant, computed by using the kinetic approach $\left(\log \mathrm{K}_{\mathrm{Fe}^{\prime} \mathrm{L}}^{\prime}=\right.$ $8.86-9.2)$, where the formation rate constant $\left(k_{\mathrm{f}}\right)$ was $3.1 \cdot 10^{5}-4.2 \cdot 10^{5} \mathrm{M}^{-1} \mathrm{~s}^{-1}$ and the dissociation rate constant $\left(k_{\mathrm{d}}\right)$ was $2.43 \cdot 10^{-4}-4.4 \cdot 10^{-4} \mathrm{~s}^{-1}$. The conditional stability was also computed from the titration approach with $\log \mathrm{K}_{\mathrm{Fe}}^{\prime} \mathrm{L}$ from 8.6 to 9.5. These studied ligands also regenerated $\mathrm{Fe}(\mathrm{II})$ in seawater from $0.05 \%$ to $11.92 \%$. The results obtained in this study suggest that polyphenols increase the persistence of dissolved Fe and should be considered as an important Fe-binding ligands in seawater to better understand the global biogeochemical cycles.

Keywords: Fe-binding ligands, complexation, polyphenols, Fe(III), Fe(II) 
Iron is involved in a variety of metabolic processes and is thus an essential micronutrient for marine microorganisms (Morel and Price, 2003). The low solubility of Fe in seawater (Liu and Millero, 2002) decreases the dissolved concentration of this metal, limiting the growth of phytoplankton in some areas of the ocean, in particular in high nutrient low chlorophyll oceanic regions (Martin et al., 1991). In seawater, the speciation of Fe is highly dominated by the complexation with organic complexes $(>99 \%)$, affecting its reactivity (Gledhill and van den Berg, 1994; Rue and Bruland, 1995) and increasing its solubility (Liu and Millero, 2002; Rue and Bruland, 1995), but most of the ligands are unknown. In general, the ligands are studied as natural ligands, a pool of organic ligands able to complex $\mathrm{Fe}$ in natural waters, participating in the Fe-uptake system of microorganisms (Shaked and Liss, 2012) by different processes. Adsorption, reduction of Fe(III) to $\mathrm{Fe}(\mathrm{II})$ in solution or in the cell wall and complexation of Fe in solution (Morel et al., 2008), and the production of organic ligands by microorganisms can make dissolved Fe (dFe) more bioavailable (Granger and Price, 1999; Hutchins et al., 1999; Maldonado and Price, 1999), although these mechanisms depends on the microorganisms and their environments (Shaked and Liss, 2012).

Fe-binding ligands are produced by cells; rupture of cells after grazing (Chase and Price, 1997; Hutchins et al., 1995; Hutchins and Bruland, 1994; Sato et al., 2007), viral lysis (Glober et al., 1997; Poorvin et al., 2011), transformation of organic materials (Boyd and Ellwood, 2010; Gerringa et al., 2006; Gledhill and Buck, 2012) and organic exudates from phytoplankton (González-Dávila et al., 1995; Rico et al., 2013; Santana-Casiano et al., 2014; Vasconcelos et al., 2002). In the ocean, the bulk of Fe-binding ligands can be ranked, according to the conditional stability constant $\left(\mathrm{K}_{\mathrm{Fe}}^{\prime} \mathrm{L}\right)$, as strong ligands $\left(\mathrm{L}_{1}-\log \right.$

$\left.53 \quad \mathrm{~K}_{\mathrm{Fe}}^{\prime} \mathrm{L}>11\right)$ and weak ligands $\left(\mathrm{L}_{2}<11\right)($ Gledhill and Buck, 2012), where the ligand 
concentration and the conditional stability constant of the formed complex is measured by competitive ligand exchange adsorptive cathodic stripping voltammetry (CLEACSV). However, this technique does not give any information about the molecular structure of organic ligands (Luther et al., 2001). In this sense, the identification of organic functional groups, which form part of the ligands in seawater or cultures, will be relevant in terms of trace metal chemistry.

There is a necessity of increase our knowledge about organic functional groups and identify them within the bulk of organic ligands in natural waters. In this sense, polyphenols have been measured in the exudates of two marine microalgae, the marine diatom Phaeodactylum tricornutum and the green algae Dunaliella tertiolecta (López et al., 2015; Rico et al., 2013; Santana-Casiano et al., 2014), as well as the effect of high metal exposition on the concentration of polyphenols excreted by the cells. The authors reported that the type of phenolic compounds and their concentrations are directly related to the metal concentrations in solution as a mechanism to keep Fe in solution or decrease the free copper concentration due to its toxicity. In addition, polyphenols such as catechol, $( \pm)$ - catechin and sinapic acid can reduce Fe(III) to Fe(II) in seawater (Santana-Casiano et al., 2014).

Polyphenols, as other ligands produced by microorganisms (amino acids or polysaccharides), can complex Fe due to the hydroxyl and carboxyl groups on their molecular structures (Andjelković et al., 2006; Brown et al., 1998; Lodovici et al., 2001; Mira et al., 2002; Re et al., 1999; Sroka and Cisowski, 2003), but these Fe-binding complexes have never been studied in seawater in terms of Fe complexation. However, polyphenols have been described as strong $\mathrm{dFe}$-binding ligands in acidic solutions $(\mathrm{pH}<$ 3; Hynes and O’Coinceanainn (2001, 2004)). 
The goal of the current investigation is to measure the formation $\left(k_{\mathrm{f}}\right)$ and dissociation $\left(k_{\mathrm{d}}\right)$ rate constants and the conditional stability constants $\left(\mathrm{K}^{\prime} \mathrm{Fe}^{\prime} \mathrm{L}\right.$ and $\left.\mathrm{K}_{\mathrm{Fe} 3+\mathrm{L}}^{\prime}\right)$ for the $\mathrm{Fe}-$ complexes with $( \pm)$ - catechin $\left(5,7,3^{\prime}, 4^{\prime}\right.$-tetrahydorxyflavan-3-ol), sinapic acid $(3,5$ dimethoxy-4-hydroxycinnamic acid) and gallic acid (3,4,5-trihydroxybenzoic acid) in seawater. These three compounds have been selected among a variety of polyphenols due to their presence in phytoplankton exudates (López et al., 2015; Rico et al., 2013; Santana-Casiano et al., 2014). These authors reported how these three organic compounds showed a higher concentration in seawater enriched with phytoplankton exudates than in natural seawater. These three compounds allow us to understand the role of three different molecular structures on the chemistry of Fe. In addition, Fe redox experiments were performed in seawater in order to determine the capability of these three model organic ligands to reduce $\mathrm{Fe}(\mathrm{III})$ to $\mathrm{Fe}(\mathrm{II})$ in seawater. These results will increase our knowledge about Fe biogeochemical cycle and the role of ligands in the chemistry of $\mathrm{Fe}$ in the ocean.

\section{MATERIAL AND METHODS}

\section{Chemicals}

Fe was determined by differential pulse cathodic stripping voltammetry (DP-CSV; Croot and Johansson (2000)). A 0.01 M solution of TAC (2-2(2-thiazolylazo)-p-cresol) (SigmaAldrich) was prepared in HPLC grade methanol (Sigma-Aldrich) once every two weeks and kept in the fridge when it was not in use (darkness and $4^{\circ} \mathrm{C}$ ). An EPPS buffer solution (N-(2-hydroxyethyl)piperazine-N';2-propanesulfonic acid; SigmaUltra) was prepared at 1.0 $\mathrm{M}$ in $1.0 \mathrm{M} \mathrm{NH}_{4} \mathrm{OH}$ (ultrapure, VWR) at $\mathrm{pH} 8.05$. The buffer solution was cleaned three times through an 8HQ (8-Hydroxyquinoline) resin column. Fe(III) stock solutions $(1.0 \mu \mathrm{M}$ and $100 \mathrm{nM})$ were prepared weekly from a Fe standard solution for atomic 
absorption spectroscopy (VWR) and acidified at $\mathrm{pH} 2$ with $\mathrm{HCl}$ (ultrapure, VWR). The stock solution of $\mathrm{Fe}(\mathrm{II})\left(4 \cdot 10^{-4} \mathrm{M}\right)$ was daily prepared using ammonium $\mathrm{Fe}(\mathrm{II})$ sulfate hexahydrate (Sigma), acidified at a pH of 2 with Suprapur $\mathrm{HCl}$ (Sigma).

The selected organic ligands, $( \pm)$ - catechin, sinapic acid and gallic acid (Sigma-Aldrich) were prepared weekly in HPLC grade methanol at $10^{-3} \mathrm{M}$ and the second stock solutions were prepared, for each experiment, in MQ water (18 M $\Omega$, Millipore) at $10^{-6} \mathrm{M}$. The molecules of these three selected organic ligands are presented in Figure 1.

The reagents were always prepared in $20 \mathrm{~mL}$ Teflon (Savilex) vials. These bottles were washed 5 times with MQ water and 2\% $\mathrm{HCl}$ (suprapure, VWR). The Teflon vials were rinsed 5 times with MQ water prior to use.

The seawater used in the current experiments was collected during the oceanographic cruise "GEOVIDE" (station $77,53.0^{\circ} \mathrm{N},-51.1^{\circ} \mathrm{E}, 40 \mathrm{~m}$ ) in the North Atlantic Ocean and was filtered on board through $0.2 \mu \mathrm{m}$-pore size cartridge filters. The GEOVIDE seawater (GSW) was kept in the clean laboratory (Class 100) facilities (LEMAR-IUEM) with acidclean carboy $(25 \mathrm{~L})$ in the dark, at room temperature, until it was used.

\section{Measurements of labile and dissolved Fe}

119 Dissolved $\mathrm{Fe}(\mathrm{dFe})$, labile $\mathrm{Fe}\left(\mathrm{Fe}^{\prime}\right.$; all the inorganic species predominantly in the form $\left.120 \mathrm{Fe}(\mathrm{OH})_{3}\right)$, and dFe-binding ligands $\left(\mathrm{L}_{\mathrm{Fe}}\right)$ concentrations were determined by DP-CSV 121 (Croot and Johansson, 2000) using a $\mu$ Autolab voltameter (Metrohm), with a static mercury drop electrode (Metrohm Model VA663), a double-junction Ag/saturated AgCl reference electrode with a salt bridge filled with $3 \mathrm{M} \mathrm{KCl}$, and a glassy carbon rod as a counter electrode. The samples were always processed in a Class 100 clean laboratory at room temperature. 
126 Labile Fe was measured in $10 \mathrm{~mL}$ seawater samples by adding $100 \mu \mathrm{L}$ of EPPS (final concentration $10 \mathrm{mM}$ EPPS buffered to $\mathrm{pH} 8.05$ ) and $10 \mu \mathrm{L}$ of $0.01 \mathrm{M}$ TAC (final concentration $10 \mu \mathrm{M})$. Samples were purged for $180 \mathrm{sec}$ with dry nitrogen gas. A new Hg drop was formed at the end of the purging time. The Teflon vials were conditioned 5 times with GSW. The labile Fe concentrations were determined using the method of standard additions. TAC was added at the beginning of the purging time, then the contact time was $180 \mathrm{sec}$.

Dissolved Fe concentrations were measured following the same method, but the samples were previously UV-irradiated during 4 hours in quartz tubes. These tubes were soaked for one day in $10 \% \mathrm{HCl}$ (suprapure, VWR) and washed with MQ water 5 times prior to use. They were also rinsed one more time with GSW. The Teflon vials were conditioned 5 times with GSW. The dFe concentration was determined using the method of standard additions. TAC was also added at the beginning of the purging time, then the contact time was $180 \mathrm{sec}$.

The voltammetric analysis was always the same for all the analysis. The deposition potential of $-0.40 \mathrm{~V}$ was applied for $180 \mathrm{sec}$. The sample was stirred during the deposition time. At the end of the deposition time, the scan as a DP-CSV was applied with a modulation time of $0.01 \mathrm{sec}$, interval time $0.1 \mathrm{sec}$, initial potential $-0.4 \mathrm{~V}$, final potential $-0.9 \mathrm{~V}$, step potential $2.55 \mathrm{mV}$ and modulation amplitude $49.95 \mathrm{mV}$.

\section{Dissolved Fe organic speciation measured using the kinetic method} $\mu \mathrm{L}$ of EPPS (1 M) buffered to $\mathrm{pH} 8.05,10 \mathrm{nM}$ of dFe, and $5 \mathrm{nM}$ of the studied ligands in at least 14 Teflon vials. These experiments were performed with an excess of Fe 
compared to ligand in order to have enough $\mathrm{dFe}$ to saturate the binding sites in the polyphenols and to achieve the maximum complexing capacity. The initial time $\left(\mathrm{t}_{0}\right)$ corresponds to the addition of the studied ligand. The addition of TAC (10 $\mu \mathrm{L}$ of $0.01 \mathrm{M})$ was performed during the purge, $20 \mathrm{sec}$ before starting the deposition time. This time was used to purge the sample after the addition of TAC. The Fe measured in the kinetic of formation experiments has to be considered as labile Fe (Gerringa et al., 2007), because there is no equilibration time between TAC and the studied ligands due to the short contact time between FeL and TAC. In irradiated seawater samples, this time was found to be enough to measure the labile Fe in solution.

The kinetic of dissociation of dFe-ligand complexes was prepared in at least 14 Teflon vials with $10 \mathrm{~mL}$ of UV-irradiated GSW (4 hours), $100 \mu \mathrm{L}$ of EPPS (1 M) buffered to $\mathrm{pH}$ $8.05,10 \mathrm{nM}$ of Fe and $5 \mathrm{nM}$ of the studied ligand. The times of equilibration for each ligand were defined, according to the formation results, when the plateau was reached (4 hrs for $( \pm)$ - catechin, 2 hrs for sinapic acid, and 15 hrs for gallic acid). Then $10 \mu \mathrm{L}$ of TAC $(0.01 \mathrm{M})$ was added into the samples, corresponding with the initial time of dissociation $\left(\mathrm{t}_{0}\right)$. In this case, as TAC and the studied ligand can compete during the dissociation, the measured $\mathrm{dFe}$ is here called 'TAC labile Fe' (Gerringa et al., 2007). The addition of TAC will form an electroactive complex which can be detected in the mercury drop.

All the experiments were carried out in triplicate and the Teflon vials were conditioned 5 times with GSW.

\section{Dissolved Fe organic speciation measured by DP-CSV}


173 In a series of 14 Teflon bottles an aliquot of $10 \mathrm{~mL}$ of natural seawater, $100 \mu \mathrm{L}$ of EPPS

174 (1 M) buffered to $\mathrm{pH} 8.05$, and different concentrations of $\mathrm{dFe}$ (from 0 to $15 \mathrm{nM}$ ) were 175 pipetted into the bottles. For GSW titrations, the solution was left to equilibrate for one 176 hour. Then, $10 \mu \mathrm{L}$ of TAC $(0.01 \mathrm{M})$ were added and left to equilibrate overnight (Croot 177 and Johansson, 2000). The samples were measured in a Teflon cell. First, two GSW sub178 samples were systematically analysed according to the recommendation of the 179 GEOTRACES program, where two +0 -dFe additions in the titration with at least eight $\mathrm{dFe}$ additions, for a total of 10 or more titration points will provide a better data interpretation (Garnier et al.,2004; Gledhill and Buck, 2012; Sander et al., 2011).

182 The dFe-binding capacities of the studied organic ligands, $( \pm)$ - catechin, sinapic acid and gallic acid, were measured following the same method as indicated in the titration approach. A solution containing $10 \mathrm{~mL}$ of UV-irradiated GSW (UV-treatment for 4 hours), $100 \mu \mathrm{L}$ of EPPS ( $1 \mathrm{M}$ ) buffered to $\mathrm{pH} 8.05,0$ to $15 \mathrm{nM}$ of $\mathrm{Fe}(\mathrm{III})$ and $2-11.8$ $\mathrm{nM}$ of the studied ligand was prepared. These solutions were equilibrated for the same time as above and, $20 \mathrm{sec}$ before the deposition time, $10 \mu \mathrm{L}$ of TAC $(0.01 \mathrm{M})$ were pipetted into the Teflon cell for measurement. This short time was selected in order to avoid equilibrium between TAC and FeL, and because the interest of this work was to measure the equilibrium between $\mathrm{Fe}$ and polyphenols.

The titration data were processed using the ProMCC program (Omanović et al., 2014) in order to compute the concentrations of ligands and the conditional stability constants.

\section{$\mathrm{Fe}(\mathrm{III})$ reduction experiments}

The Fe(III) reduction experiments were carried out according to Santana-Casiano et al. 
in a $200 \mathrm{ml}$ thermostatted vessel controlled to $25 \pm 0.02{ }^{\circ} \mathrm{C}$ and $\mathrm{pH} 8.0 \pm 0.01$. The $\mathrm{pH}$ of the solution was determined on the free scale, $\mathrm{pH}_{\mathrm{F}}$ (Millero, 1986). The $\mathrm{pH}$ was adjusted to the desired value with additions of small amounts of $1 \mathrm{M} \mathrm{HCl}$, automatically controlled by a 719 titrinoTM (Methrom) to keep it constant. This Fe concentration was used to reproduce the same experiments as carried out by Santana-Casiano et al. (2010, 2014) and to ensure that the preparation of the polyphenols stock solutions in methanol and MQ did not have any effect on the Fe(II) reduction process and be able to compare the current study with the literature. The solution was initially aerated with air for two hours under oxygen saturation conditions in order to fully oxidize the added Fe(II) solution. After that time, $10^{-4} \mathrm{M}$ ferrozine (FZ) was added. Fe(II) was not detected in the absence of the phenolic compounds. The addition of $100 \mathrm{nM}$ of the polyphenol corresponds to zero time of reaction. The Fe(II)-FZ complex was recorded over time at $562 \mathrm{~nm}$ in a 5-m-long waveguide capillary flow cell (LWCFC) from World Precision Instruments connected to the UV detector S4000 (Ocean OpticsTM). This technique allows to measure both $\mathrm{Fe}(\mathrm{II})$ and the organic compounds. Every acquisition time, the absorbance spectrum was analysed to correct the baseline (Santana-Casiano et al., 2010). These experiments will enable us to detect if Fe(II) is formed during the equilibration time between $\mathrm{dFe}$ and the studied polyphenols.

\section{RESULTS}

\section{Dissolved Fe concentration in the seawater}

The $\mathrm{dFe}$ in the natural seawater used in the current investigation was $0.36 \pm 0.06 \mathrm{nM}$ (n $=8)$ and the $\mathrm{Fe}^{\prime}$ was $0.020 \pm 0.004 \mathrm{nM}(\mathrm{n}=8)$. Then, the FeL in the natural seawater sample was $\sim 95 \%$. Figure 2 shows one of the titrations carried out by additions of Fe ( 0 $-15 \mathrm{nM})$ to the GSW and the UV-irradiated GSW. These results show that the natural 
222 ligand concentration calculated using the ProMCC code was $3.1 \pm 0.7 \mathrm{nM}(\mathrm{n}=10)$. This

223

224

225

226

227

228

229

230

231

232

234

235

236

237 seawater contained 8 times more ligands than $\mathrm{dFe}$. The conditional stability constant was $\log \mathrm{K}_{\mathrm{Fe}^{\prime} \mathrm{L}}^{\prime}=11.5 \pm 0.4$ in respect to $\mathrm{Fe}^{\prime}$ and $\log \mathrm{K}_{\mathrm{Fe} 3+\mathrm{L}}^{\prime}=21.5$. Therefore, the ligands in GSW are ranked as L2-type ligands (Gledhill and Buck, 2012). No significant differences were observed between linear (van den Berg and Kramer, 1979) and non-linear treatment (Gerringa et al., 2014; Pižeta et al., 2015). The standard error from the ProMCC for each analysis in terms of $\mathrm{K}^{\prime} \mathrm{Fe}^{\prime} \mathrm{L}$ and ligand concentration was always at least one order of magnitude lower than the same parameter.

\section{Dissolved Fe speciation from the kinetic approach}

In order to study the Fe-binding capacity of polyphenols in terms of kinetic experiments, the GSW was UV-irradiated during 4 hours. This was long enough to decompose all the organic ligands, as demonstrated by the linear dependence of the peak high (nA) and the Fe concentrations (Figure 2). The concentration of dFe did not exceed the solubility of Fe in our seawater samples because the standard additions were linear in the studied range (15 $\mathrm{nM}$ of $\mathrm{dFe}$ ). However, the linear standard additions can also occur when formation kinetics are quick and TAC dissolves amorphous Fe oxides rapidly. The height peak (dFe concentration) after $10 \mathrm{nM}$ of dFe addition was followed in UV-irradiated GSW by more than $24 \mathrm{~h}$ and it was stable. These experiments were also done by triplicate in at least 14 Telfon vials.

The kinetic approach was performed according with Witter and Luther (1998) and Wu and Luther (1995). The $\mathrm{K}^{\prime} \mathrm{Fe}^{\prime} \mathrm{L}$ can be estimated from $k_{\mathrm{f}}$ and $k_{\mathrm{d}}$ by following Equation 1 where $k_{\mathrm{f}}$ and $k_{\mathrm{d}}$ where computed from the experimental results showed in Figure 3. 


$$
K_{F e / L}^{\prime}=k_{f} / k_{d}
$$

In addition, the conditional stability constant with respect to $\mathrm{Fe}^{3+}\left(\mathrm{K}^{\prime} \mathrm{Fe} 3+\mathrm{L}\right)$ can be

249 calculated by assuming that the second-order rate constant is $k_{\mathrm{f}, \mathrm{Fe} 3+\mathrm{L}}=3.02 \cdot 10^{11} \mathrm{M}^{-1} \mathrm{~s}^{-1}$, previously estimated from encounter theory (Luther and $\mathrm{Wu}, 1997)$.

where $\left[\mathrm{Fe}^{\prime}\right]$ is labile $\mathrm{Fe}$ as was described above and $\mathrm{Fe}^{3+}$ is the free inorganic $\mathrm{Fe}$ (Stockdale et al., 2016), $\alpha_{\mathrm{Fe}^{\prime}}=10^{10}$ (Hudson et al., 1992; Sunda and Huntsman, 2003), is commonly used for $\mathrm{pH} 8$ seawater. Then, the dissociation rate constant $k_{\mathrm{d}, \mathrm{Fe} 3+\mathrm{L}}$ can be computed (Equation 3).

$$
k_{d, F e^{3+} L}=\frac{k_{f, F e^{3+} L}}{K_{F e^{3+} L}^{\prime}}
$$

260

261

The half-life time $\left(\mathrm{t}_{1 / 2}\right)$, for $\mathrm{Fe}^{\prime} \mathrm{L}$ and $\mathrm{Fe}^{3+} \mathrm{L}$, has also been computed according to the pseudo-first kinetic equation, which can be expressed as: $t_{1 / 2}=\ln 2 / k_{d}$.

263 In addition, the presence of organic ligands enhances Fe solubility by favoring the formation of small Fe soluble species (Kuma et al., 1996).

The results for the kinetic of formation and dissociation experiments are shown in Figure 3 and Table 1 . They showed that the $\mathrm{dFe}-$ phenolic complexes are rapidly formed with $\log k_{\mathrm{f}}$ between $5.50-5.62\left(k_{\mathrm{f}}\right.$ in $\mathrm{M}^{-1} \mathrm{~s}^{-1}$, Table 1$)$. On the other hand, the dissociation rate constants were also high; $\log k_{\mathrm{d}}-3.36-3.61\left(k_{\mathrm{d}}\right.$ in $\mathrm{s}^{-1}$, Table 1$)$ for these polyphenol 
groups. Then, the $\log \mathrm{K}^{\prime} \mathrm{Fe}^{\prime} \mathrm{L}$ determined from the kinetic experiments were equal to $9.2 \pm$ $0.1(( \pm)-$ catechin), $8.86 \pm 0.04$ (sinapic acid) and $9.01 \pm 0.02$ (gallic acid)), relative to the $\mathrm{Fe}^{\prime}$ species. These Fe-organic complexes can be defined as weak ligands $\left(\mathrm{L}_{2}\right.$-type ligands; Gledhill and Buck (2012)). According to the dissociation rate constants, the presence of polyphenols will keep dFe in solution from $11.3 \mathrm{~min}$ to $20.6 \mathrm{~min}$, in respect to the complex of Fe' with sinapic acid or $( \pm)$ - catechin, respectively. This half-life time increased to the order of years $(0.32-0.54)$ in terms of $\mathrm{Fe}^{3+}$ (Table 1$)$. This difference is due to the calculation of half-life time for $\mathrm{Fe}^{3+} \mathrm{L}$ complexes assumes an upper diffusion control limit to formation of the complex rather than the activation control for $\mathrm{Fe}^{\prime} \mathrm{L}$ (Witter et al., 2000).

\section{Conditional stability constants from CLE-CSV}

The total amounts of organic ligands in seawater can be computed using Equation (4).

$$
\left[L_{T}\right]=\left[L^{\prime}\right]+[F e L]
$$

where $\left[\mathrm{L}_{T}\right]$ is the total concentration of ligands, [L'] includes both free ligands and ligands complexed with other major cations in seawater $\left(\right.$ as $\mathrm{Ca}^{2+}, \mathrm{Mg}^{2+}$ and $\mathrm{H}^{+}$; Rue and Bruland (1995)), [FeL] the concentration of Fe-binding ligands. In the same sense, the concentration of $\mathrm{Fe}$ in solutions can be considered as Equation 5.

$$
[F e]_{T}=\left[F e^{\prime}\right]+[F e L]
$$


where $[\mathrm{Fe}]_{\mathrm{T}}$ represents the total dissolved $\mathrm{Fe}$ in seawater, $\left[\mathrm{Fe}^{\prime}\right]$ represents the concentration of all the inorganic species (predominantly in the form $\mathrm{Fe}(\mathrm{OH})_{3}$ (Stockdale et al., 2016). The equilibrium system between Fe and the organic ligand is:

where the conditional stability constant with respect to $\left[\mathrm{Fe}^{\prime}\right]$ is expressed as Equation 7:

$$
F e^{\prime}+L^{\prime} \leftrightarrow F e L
$$

\section{7}

$$
K_{F e L}^{\prime}=\frac{[F e L]}{\left[F e^{\prime}\right]\left[L^{\prime}\right]}
$$

1

The relationship between $\mathrm{Fe}^{\prime}$ and $\mathrm{Fe}^{3+}$ can be used as: $\alpha_{F e^{\prime}}=\left[F e^{\prime}\right] /\left[F e^{3+}\right]$, then $K_{F e^{\prime} L}^{\prime}=$ $\alpha_{F e^{\prime}} K_{F e^{3+}{ }_{L}}^{\prime}$, where $\alpha_{\mathrm{Fe}^{\prime}}=10^{10}$ (Hudson et al., 1992; Sunda and Huntsman, 2003) is commonly used for $\mathrm{pH} 8$ seawater and the $\mathrm{K}^{\prime} \mathrm{Fe}^{\prime} \mathrm{L}$ can then be calculated from the values of Fe'measured by CSV and the dFe and L concentrations using Equations 4, 5 and 7.

The complexation of dFe by the three different polyphenols, $( \pm)$ - catechin, sinapic acid and gallic acid, was studied in UV-irradiated GSW (Table 2). Two different concentrations of the studied Fe-binding ligands were used in order to evaluate if the binding capacity was related to the concentration and to determine if the binding sites were saturated with those Fe levels in every sample. The ligand $( \pm)$ - catechin was able to complex $1.6 \pm 0.2 \mathrm{nM}$ and $3.6 \pm 0.5 \mathrm{nM}$ of $\mathrm{dFe}$ when 5.7 and $11.8 \mathrm{nM}$ of the studied ligand were present in solution, with a $\log \mathrm{K}_{\mathrm{Fe}}^{\prime} \mathrm{L}$ between $9.3-9.1$, respectively. Sinapic acid complexed $3.6 \pm 0.8$ and $6.5 \pm 0.7 \mathrm{nM}$ of dFe when 5.0 and $9.9 \mathrm{nM}$ of the ligand were added, with a $\log \mathrm{K}_{\mathrm{Fe}}^{\prime} \mathrm{L}=8.6$. Finally, when $2.0 \mathrm{nM}$ of gallic acid was added, $5.5 \pm$ $0.3 \mathrm{nM}$ of $\mathrm{dFe}$ was organically complexed and when $5 \mathrm{nM}$ of gallic acid was added to the UV-seawater, $14 \pm 2 \mathrm{nM}$ of $\mathrm{dFe}$ were found complexed. The amount of Fe complexed or 
removed by gallic acid was always over double the added ligand concentration. The log

$318 \mathrm{~K}_{\mathrm{Fe}}^{\prime} \mathrm{L}$ values were 8.8 and 9.5, respectively.

319 Taking into account the titration approach, the $\log \mathrm{K}_{\mathrm{Fe}^{\prime} \mathrm{L}}^{\prime}$ was from 8.6 to 9.5 (Table 2).

320 Accordingly, the studied ligands formed weak organic complexes with dFe in seawater,

321 with a conditional stability constant $\geq 18$ with respect to $\mathrm{Fe}^{3+}$. Then, they can be classified

322 as $\mathrm{L}_{2}$-type organic ligands (Gledhill and Buck, 2012).

\section{Fe(III) reduction by polyphenols in seawater}

325

326

327

$\mathrm{Fe}(\mathrm{III})$ is reduced by $( \pm)$ - catechin, sinapic acid and gallic acid in UV-irradiated GSW at $\mathrm{pH} 8.0$ and $25^{\circ} \mathrm{C}$ (Figure 4). The Fe(III) reduction rate constant (pseudo-first order rate constant) was $8.98 \pm 0.02 \cdot 10^{-7} \mathrm{sec}^{-1}, 1.45 \pm 0.02 \cdot 10^{-7} \mathrm{sec}^{-1}$ and $3.90 \pm 0.04 \cdot 10^{-5} \mathrm{sec}^{-1}$ for $( \pm)$ - catechin, sinapic acid and gallic acid, respectively. This means that $100 \mathrm{nM}$ of polyphenol are able to reduce from $0.05 \mathrm{nM}$ to $11.92 \mathrm{nM}$ of Fe(III) in one hour of reaction in UV-irradiated GSW. Then, at equimolar concentration (100 $\mathrm{nM}$ of $\mathrm{dFe}$ and the studied organic ligand), the studied polyphenols were able to reduce $\mathrm{Fe}(\mathrm{III})$ to $\mathrm{Fe}(\mathrm{II})$ in seawater.

\section{DISCUSSION}

\section{Polyphenols as dFe-complexing ligands in seawater}

Recent investigations (López et al., 2015; Rico et al., 2013; Santana-Casiano et al., 2010, 2014) demonstrated that polyphenols have to be considered as important organic ligands within the Fe biogeochemical cycle due to their ability to reduce $\mathrm{Fe}$ (III) to $\mathrm{Fe}$ (II) in seawater as well as to be produced in the microalgae exudates as a response to the Fe exposition. According to the molecular structure (Figure 1), $( \pm)$ - catechin is a flavonoid 
type compound with a catechol moiety in the B-ring, a resorcinol group in the A-ring and a hydroxyl group at position 3 in the C-ring (Figure 1A). Sinapic acid is a phenylpropanoid compound, with 3,5-dimethoxyl and 4-hydroxyl groups substituting the phenyl group of the cinnamic acid (Figure 1B). Gallic acid is tri-hydroxybenzoic acid (gallyol moiety) (Figure 1C). Such acids are generally forming dimers such as ellagic acid. $( \pm)$ - catechin, sinapic acid and gallic acid contain $-\mathrm{OH}$ groups in their molecules which at $\mathrm{pH} \sim 8$ (natural seawater $\mathrm{pH}$ ) should be deprotonated forming anionic ligands capable of complexing metals, as the organic ligands at the cell surface of microorganisms (González et al., 2014). Accordingly, polyphenols at natural pH complex dFe in seawater, as it was previously reported at acidic $\mathrm{pH}$ and low ionic strength solutions (Andjelković et al., 2006; Brown et al., 1998; Hynes and O'Coinceanainn, 2004; Khokhar and Apenten, 2003; Mira et al., 2002).

In general, the $\mathrm{dFe}$ complexation by polyphenols is related to the presence of the orthodi-hydroxy groups, mainly present in molecules bearing catechol or gallyol moieties (Khokhar and Apenten, 2003; Moran et al., 1997) and to the amount of -OH groups in each molecule. In fact, Andjelković et al. (2006) demonstrated that polyphenols bearing gallyol groups form stronger chelates than molecules with catechol moiety in aqueous solutions. The formation of complexes between $\mathrm{dFe}$ and the organic ligands proposed in this investigation showed that gallic acid is the most important phenolic compound in terms of dFe-binding capacity, where a stoichiometric ratio 1:1 can be assumed (Table 2). The differences in the complexing capacity could not only be understood as a role of the hydroxyl groups in the catechol or gallyol moieties in seawater. The presence of major ions such as $\mathrm{Mg}^{2+}$ and $\mathrm{Ca}^{2+}$ play a key role in the oxidation process of polyphenols, blocking the reaction to semiquinone and benzoquinone (Santana-Casiano et al., 2010, 2014). Then, some of the $-\mathrm{OH}$ groups are occupied by $\mathrm{Mg}^{2+}$ and $\mathrm{Ca}^{2+}$, decreasing their 
capacity to complex dFe (Santana-Casiano et al., 2010, 2014). In addition, the ability of gallic acid to form dimers in solution can be involved in the higher dFe-binding capacity compared to that for $( \pm)$ - catechin and sinapic acid.

The kinetics of formation did not reveal a very strong decrease in the labile Fe in the first seconds (Figure 3), as it occurs for stronger ligands, $\mathrm{L}_{1}$-type ligands, such as protoporphyrin IX (Witter et al., 2000), with a decrease of $2 \mathrm{nM}$ of Fe within the first seconds of the reaction, supporting the experimental results for polyphenols that are ranked as weak ligands. The polyphenols studied in this manuscript progressively decreased the labile Fe over time (Figure 3). Other studied ligands have also been characterized in terms of formation rate constant in seawater (Witter et al., 2000) such as protoporphyrin IX, phaeophytin, apoferritin, phytic acid, alterobactin A and B, ferrichrome and desferrioxamine, with $k_{\mathrm{f}}$ from $0.93 \cdot 10^{5}$ to $19.6 \cdot 10^{5} \mathrm{M}^{-1} \mathrm{~s}^{-1}$. These authors (Witter et al., 2000), also reported the dissociation rate constant for the same organic binding ligands and ranked from $0.05 \cdot 10^{-6}$ to $15.8 \cdot 10^{-6} \mathrm{~s}^{-1}$. The data collected from the literature for natural waters show a high variability (from $0.31 \cdot 10^{-6}$ to $39 \cdot 10^{-6}$; Luther et al. (1997) and Witter et al. (1998), which proves the huge diversity of ligands in the water.

The dissociation rate constant allows to compute the half-life time of Fe in solution, both as $\mathrm{Fe}^{\prime}$ and $\mathrm{Fe}^{3+}$ (Table 1). In the presence of polyphenols, Fe' half-life time is $11-21 \mathrm{~min}$, which increases to $0.3-0.5$ years when $\mathrm{Fe}^{3+}$ species are considered. It means that $\mathrm{Fe}$ persists in solution longer periods when polyphenols are present. These $t_{1 / 2}$ are highly affected by the presence of organic ligands in the ocean and ranked from minutes to years (Witter et al., 2000).

The $\log \mathrm{K}_{\mathrm{Fe}}^{\prime} \mathrm{L}$ values estimated from the kinetic experiments for $( \pm)$ - catechin, sinapic acid and gallic acid are weaker than other model ligands studied by Witter et al. (2000) which $\log \mathrm{K}_{\mathrm{Fe}^{\prime} \mathrm{L}}^{\prime}$ values were $10.8-13.0$, and also with humic substances $\left(\log \mathrm{K}_{\mathrm{Fe}^{\prime} \mathrm{L}}^{\prime}=\right.$ 
11.1; Laglera et al. (2011)) and fulvic acids ( $\log \mathrm{K}^{\prime}{ }_{\mathrm{Fe}}^{\prime} \mathrm{L}=10.6-10.9$; Laglera et al. (2011; Laglera and van den Berg (2009), exudates from Pseudonana antarctica (log $\mathrm{K}^{\prime}{ }_{\mathrm{Fe}}^{\prime} \mathrm{L}=$ 11.9; Norman et al., 2015) and Emiliania huxleyi ( $\log \mathrm{K}_{\mathrm{Fe}^{\prime} \mathrm{L}}^{\prime}=11.9$; Boye and van den Berg, 2000).

According to the recovery of ligands with respect to the initial addition, a tentative stoichiometry can be computed. The $( \pm)$ - catechin and sinapic acid followed the same trend, the concentration of the recovered ligand was always lower than the added ligand, and the recovered ligand concentration in the titration approach (Table 2) is comparable with the FeL formation in the kinetic experiments (Figure 3). However, the addition of a certain concentration of gallic acid always resulted in a higher concentration of recovered ligand or FeL formation in both approaches (Table 2 and Figure 3). The addition of $( \pm)-$ catechin was increased from 5.7 to $11.8 \mathrm{nM}$ (2.07-fold) and the recovered ligands was 2.25-fold. Attending to sinapic acid, the added level increased by 2.0 (Table 2) and the recovered ligand increased by 1.8 -fold. Then, a tentative stoichiometry of $1: 1$ ligand-tometal complexes can be assumed. The gallic acid is the only case where the addition of a certain level resulted in a higher recovered concentration. Then, in this case, the relationship between FeL and added $\mathrm{L}$ was $\sim 3$ (Table 2). In the literature, there are conflicting results for Fe-gallic acid complexes where the stoichiometry can be from 1:1 to 1:3 metal-to-ligand complexes (Andjelković et al., 2006; Fazary et al., 2008; Powell and Taylor, 1982; Strlič et al., 2002) as well as 1:1 and 2:1 metal-to-ligand complexes (Hynes and O'Coinceanainn, 2001), demonstrating the complicated nature of these type of ligands in solution, where the binding capacity is function of the $\mathrm{pH}$, the composition of the solution, the reactivity of the gallic acid to reduce $\mathrm{Fe}(\mathrm{III})$ to $\mathrm{Fe}(\mathrm{II})$ and the formation of other molecules such as quinone, semiquinone or tannic acids (Andjelković et al., 
complex Fe in a higher ratio. In addition, Strlič et al. (2002) reported the role of the Fe:gallic acid complexes in terms of the $\mathrm{HO}^{\circ}$ production that also have an impact on $\mathrm{Fe}$ redox chemistry. Then, further experiments will be carried out in order to elucidate the Fe:gallic acid stoichiometry in seawater. For this purpose, an evaluation of binding capacity will be studied by using a combination of UV-Vis absorption spectroscopy (Andjelković et al., 2006) and voltammetric technique (this study) as a function of dFe and gallic acid concentration in seawater.

\section{Polyphenols as a source of $\mathrm{Fe}(\mathrm{II})$ in seawater}

The complexation of $\mathrm{dFe}$ with polyphenols can be considered as a first step in the process of internalization of Fe by phytoplankton, reducing $\mathrm{Fe}(\mathrm{III})$ to $\mathrm{Fe}(\mathrm{II})$ both in seawater (Santana-Casiano et al., 2010, 2014) and at cell surfaces (González et al., 2014). The same mechanism was also studied for catechol (Santana-Casiano et al., 2010), $( \pm)$ catechin and sinapic acid (Santana-Casiano et al., 2014) as a function of $\mathrm{pH}$. Polyphenols form a complex with $\mathrm{Fe}(\mathrm{III})$ and reduce a fraction of $\mathrm{Fe}(\mathrm{III})$ to $\mathrm{Fe}(\mathrm{II})$, as it has been shown in the current manuscript. The reduction rate constants (in $\left.\log k^{\prime}\right)$ for $( \pm$ ) - catechin and sinapic acid are comparable with those measured by Santana-Casiano et al. (2014), where $k^{\prime}$ was $7.02 \cdot 10^{-7} \mathrm{~s}^{-1}$ and $2.67 \cdot 10^{-7} \mathrm{~s}^{-1}$, respectively. Gallic acid showed a higher $\log k^{\prime}$ that is in the same range as that for catechol (Santana-Casiano et al., 2010). In addition, the organic exudates excreted by $P$. tricornutum also retarded the Fe(II) oxidation rate constant in seawater (González et al., 2012; Santana-Casiano et al., 2014). From the current results, we can conclude that organic exudates such as polyphenols increase the persistence of $\mathrm{Fe}(\mathrm{II})$ in seawater, either by decreasing their oxidation rate constant to $\mathrm{Fe}(\mathrm{III})$ and/or by reducing $\mathrm{Fe}(\mathrm{III})$ to $\mathrm{Fe}(\mathrm{II})$. 


\section{Possible discrepancies between kinetic and titration approaches}

441 The experimental methods used in the current manuscript will allow to determine the

442 conditional equilibrium constant for Fe-binding ligands as well as the concentration of these ligands in solution. The calculation of these parameters is highly dependent on the pH and major ions (Laglera et al., 2001).

In the current manuscript, the comparison between kinetic and titration approaches are in a good agreement for $( \pm)$ - catechin and sinapic acid, but there are significant differences in the determination of FeL concentration when gallic acid was studied. These differences can be understood as a consequence of the combination of a number of possible factors acting on the experimental approach, such as Fe(II) production during the formation reaction time, the oxidation of gallic acid to semiquinone or quinone groups and the

451 formation of other organic molecules from gallic acid. In the experimental approach, all non-labile Fe is assumed to be complexed by the organic ligand, which can be the case for catechin and sinapic acid, while for gallic acid, other processes could be acting. Therefore, the constant provided in this study should be considered a global complexation constant for any Fe present in the solution. There is an important discrepancy about the Fe:gallic acid stoichiometry in the literature because its reaction mechanism dependent on $\mathrm{pH}$, ionic strength and concentrations of both chemical (Andjelković et al., 2006; Fazary et al., 2008; Hynes and O'Coinceanainn, 2001; Powell and Taylor, 1982; Strlič et al., 2002). Further experiments are necessary to properly define the Fe:gallic acid stoichiometry in seawater by a combination of techniques and physico-chemical conditions. 
462 Accordingly, the $\mathrm{Fe}(\mathrm{II})$ regeneration during the formation reaction and during the equilibration between $\mathrm{dFe}$ and polyphenols can also invoke a slight discrepancies in terms of ligand concentration and conditional stability constant. During the equilibration time between Fe and the studied ligands ( $>2$ hours), a fraction of Fe(III) can be reduced to $\mathrm{Fe}(\mathrm{II})$ and when TAC is added to the titration vials, this fraction of $\mathrm{Fe}$ is not reacting with TAC as $\mathrm{Fe}(\mathrm{III})$. It was determined that during $1 \mathrm{~h}$ of equilibration between $\mathrm{dFe}$ and the studied polyphenols, from $0.05 \%$ to $11.92 \%$ of Fe(II) is formed. Then, the calculation of the conditional stability constant and ligand concentration from the titration can be overestimated.

471 In the case of polyphenols, the interaction with $\mathrm{Mg}^{2+}$ and $\mathrm{Ca}^{2+}$ affects the oxidation of the semiquinone radical to quinone and it may affect the Fe chemistry, both in terms of complexation and in terms of redox reactions, and it has been demonstrated for catechol, $( \pm)$ - catechin and sinapic acid (Santana-Casiano et al., 2010, 2014). Moreover, during the equilibration time between Fe and the studied ligands, the competition with the $\mathrm{MgL}$ and CaL could affect the dFe-ligand complexation (Hering and Morel, 1988; Raspor et al., 1980; Wu and Luther, 1995), which becomes more relevant when weak ligands are in solution. This competition between $\mathrm{Fe}$ with $\mathrm{Ca}$ and $\mathrm{Mg}$ for the binding sites can introduce an interference for the calculation of the ligand concentration as well as of the conditional stability constant.

These artefacts are more relevant for weak ligands than for strong ligands. Therefore, the kinetic approach seems more consistent for use in future experiments defining the complexation of $\mathrm{dFe}$ and studied ligands in seawater. 
Polyphenols as model dFe-binding ligands are excreted by phytoplankton and can play two different roles in terms of the Fe biogeochemical cycle. On one hand, the polyphenols can complex dFe in seawater, and on the other hand, these polyphenols can reduce Fe(III) to $\mathrm{Fe}(\mathrm{II})$. Among the pool of binding ligands, $( \pm)$ - catechin, sinapic acid and gallic acid have been thermodynamically characterized. The formation rate constant $\left(k_{\mathrm{f}}\right)$ measured for the complex between $\mathrm{dFe}$ and $( \pm)$ - catechin, sinapic acid and gallic acid, varied from $3.14 \cdot 10^{5}$ to $4.17 \cdot 10^{5}\left(\mathrm{M}^{-1} \mathrm{~s}^{-1}\right)$. The dissociation rate constant $\left(k_{\mathrm{d}}\right)$ varied from $2.43 \cdot 10^{-4}$ to $4.4 \cdot 10^{-4}\left(\mathrm{~s}^{-1}\right)$. The conditional stability constants using the kinetic approach were also calculated $\left(\log \mathrm{K}_{\mathrm{Fe}^{\prime} \mathrm{L}}^{\prime}=8.86-9.2\right)$. These conditional stability constants were compared with the titration approach, where the $\log \mathrm{K}_{\mathrm{Fe}}^{\prime} \mathrm{L}$ values were from 8.6 to 9.5 for the three studied Fe-binding ligands. These polyphenols are within the $\mathrm{L}_{2}$-type ligands. Moreover, $\mathrm{Fe}(\mathrm{III})$ is reduced by $( \pm)$ - catechin, sinapic acid and gallic acid in seawater, promoting the formation of $\mathrm{Fe}$ (II) from $0.05 \%$ to $11.92 \%$. Taking these results into consideration, polyphenols should be considered as an important dFe-binding ligands in seawater in order to properly understand the biogeochemical cycle of Fe and organic ligands.

\section{References}

Andjelković, M., Van Camp, J., De Meulenaer, B., Depaemelaere, G., Socaciu, C., Verloo, M., Verhe, R., 2006. Iron-chelation properties of phenolic acids bearing catechol and galloyl groups. Food Chem. 98, 23-31. https://doi.org/10.1016/j.foodchem.2005.05.044

Boyd, P.W., Ellwood, M.J., 2010. The biogeochemical cycle of iron in the ocean. Nat. Geosci. 3, 675-682. https://doi.org/10.1038/ngeo964

Boye, M., van den Berg, C.M.G., 2000. Iron availability and the release of iron- 

complexing ligands by Emiliania huxleyi. Mar. Chem. 70, 277-287. https://doi.org/10.1016/S0304-4203(00)00032-3

512 Brown, J.E., Khodr, H., Hider, R.C., Rice-Evans, C.A., 1998. Structural dependence of 513 flavonoid interactions with $\mathrm{Cu}^{2+}$ ions: implications for their antioxidant properties. $514 \quad$ Biochem. J. https://doi.org/10.1042/bj3301173

515 Chase, Z., Price, N.M., 1997. Metabolic consequences of iron deficiency in heterotrophic marine protozoa. Limnol. Oceanogr. 42, 1673-1684. https://doi.org/10.4319/1o.1997.42.8.1673

Croot, P.L., Johansson, M., 2000. Determination of iron speciation by cathodic stripping voltammetry in seawater using the competing ligand 2-(2- thiazolylazo)-p-cresol (TAC). Electroanalysis 12, 565-576.

Fazary, A.E., Taha, M., Ju, Y.H. 2008. Iron complexation studies of gallic acid. Journal of Chemical and Engineering Data, 54(1), 35-42.

Garnier, C., Pižeta, I., Mounier, S., Bena1m, J. Y., \& Branica, M. (2004). Influence of the type of titration and of data treatment methods on metal complexing parameters determination of single and multi-ligand systems measured by stripping voltammetry. Anal. Chim. Acta. 505(2), 263-275.

Gerringa, L.J.A.A., Veldhuis, M.J.W.W., Timmermans, K.R., Sarthou, G., de Baar, H.J.W.W., 2006. Co-variance of dissolved Fe-binding ligands with phytoplankton characteristics in the Canary Basin. Mar. Chem. 102, 276-290. https://doi.org/10.1016/j.marchem.2006.05.004

Gerringa, L.J.A., Herman, P.M.J., Poortvliet, T.C.W., 1995. Comparison of the linear van den Berg/Ružić transformation and a non-linear fit of the Langmuir isotherm applied 
to $\mathrm{Cu}$ speciation data in the estuarine environment. Mar. Chem. 48, 131-142. https://doi.org/10.1016/0304-4203(94)00041-B

Gerringa, L. J., Rijkenberg, M. J., Thuróczy, C. E., Maas, L. R., 2014. A critical look at the calculation of the binding characteristics and concentration of iron complexing ligands in seawater with suggested improvements. Environ. Chem. , 11(2), 114-136.

Gerringa, L.J.A., Rijkenberg, M.J.A., Wolterbeek, H.T., Verburg, T.G., Boye, M., de Baar, H.J.W., 2007. Kinetic study reveals weak Fe-binding ligand, which affects the solubility of $\mathrm{Fe}$ in the Scheldt estuary. Mar. Chem. 103, 30-45. https://doi.org/10.1016/j.marchem.2006.06.002

Gledhill, M., Buck, K.N., 2012. The organic complexation of iron in the marine environment: A review. Front. Microbiol. 3, 1-17. https://doi.org/10.3389/fmicb.2012.00069

Gledhill, M., van den Berg, C.M.G., 1994. Determination of complexation of iron (III ) with natural organic complexing ligands in seawater using cathodic stripping voltammetry. Mar. Chem. 47, 41-54. https://doi.org/10.1016/0304-4203(94)900124

Glober, C.J., Hutchins, D.A., Fisher, N.S., Cosper, E.M., Sañudo-Wilhelmy, S.A., 1997. Release and bioavailability of $\mathrm{C}, \mathrm{N}$ and $\mathrm{Fe}$ following virial lysis of a marine chrysophyte. Limnol.Oceanogr. 42, 1492-1504.

González-Dávila, M., Santana-Casiano, J.M., Pérez-Peña, J., Millero, F.J., 1995. Binding of $\mathrm{Cu}(\mathrm{II})$ to the surface and exudates of the alga Dunaliella tertiolecta in seawater. Environ. Sci. Technol. 29, 289-301.

González, A.G., Pokrovsky, O.S., Jiménez-Villacorta, F., Shirokova, L.S., Santana- 
Casiano, J.M., González-Dávila, M., Emnova, E.E., 2014. Iron adsorption onto soil and aquatic bacteria: XAS structural study. Chem. Geol. 372, 32-45. https://doi.org/10.1016/j.chemgeo.2014.02.013

González, A.G., Santana-Casiano, J.M., González-Dávila, M., Pérez, N., 2012. Effect of organic exudates of Phaeodactylum tricornutum on the Fe(II) oxidation rate constant. Ciencias Mar. 38.

Granger, J., Price, N.M., 1999. The importance of siderophores in iron nutrition of heterotrophic marine bacteria. Limnol. Oceanogr. 44, 541-555.

Hering, J.G., Morel, F.M.M., 1988. Kinetics of trace metal complexation: role of alkalineearth metals. Environ. Sci. Technol. 22, 1469-1478. https://doi.org/10.1021/es00177a014

Hudson, R.J.M., Covault, D.T., Morel, F.M.M., 1992. Investigations of iron coordination and redox reactions in seawater using ${ }^{59} \mathrm{Fe}$ radiometry and ion-pair solvent extraction of amphiphilic iron complexes. Mar. Chem. 38, 209-235. https://doi.org/10.1016/0304-4203(92)90035-9

Hutchins, D.A., Bruland, K.W., 1994. Grazer-mediated regeneration and assimilation of Fe, Zn and Mn from planktonic prey. Mar. Ecol. Prog. Ser. 110, 259-269.

Hutchins, D.A., Wang, W.X., Fisher, N.S., 1995. Copepod grazing and the biogeochemical fate of diatom iron. Limnol. Oceanogr. 40(5), 989-994. https://doi.org/10.4319/lo.1995.40.5.0989

Hutchins, D.A., Witter, A.E., Butler, A., Luther, G.W., 1999. Competition among marine phytoplankton for different chelated iron species. Nature 400, 858-861. https://doi.org/10.1038/23680 
579 Hynes, M., O’Coinceanainn, M., 2001. The kinetics and mechanisms of the reaction of iron (III) with gallic acid, gallic acid methyl ester and catechin. Journal of Inorganic Biochemistry, 85(2-3), 131-142.

582

583

584

585

586

587

588

589

590

591

592

593

594

595

596

597

598

599

600

601

Hynes, M.J., O’Coinceanainn, M., 2004. The kinetics and mechanisms of reactions of iron(III) with caffeic acid, chlorogenic acid, sinapic acid, ferulic acid and naringin. J. Inorg. Biochem. 98, 1457-1464. https://doi.org/10.1016/j.jinorgbio.2004.05.009

Khokhar, S., Apenten, R.K.., 2003. Iron binding characteristics of phenolic compounds: Some tentative structure-activity relations. Food Chem. 81, 133-140. https://doi.org/10.1016/S0308-8146(02)00394-1

Kuma, K., Nishioka, J., Matsunaga, K., 1996. Controls on iron(III) hydroxide solubility in seawater: The influence of $\mathrm{pH}$ and natural organic chelators. Limnol. Oceanogr. 41, 396-407. https://doi.org/10.4319/1o.1996.41.3.0396

Laglera-Baquer, L. M., González-Dávila, M., and Santana-Casiano, J. M., 2001. Determination of metallic complexing capacities of the dissolved organic material in seawater. Scientia Marina, 65(S1), 33-40.

Laglera, L.M., Battaglia, G., van den Berg, C.M.G., 2011. Effect of humic substances on the iron speciation in natural waters by CLE/CSV. Mar. Chem. 127, 134-143. https://doi.org/10.1016/j.marchem.2011.09.003

Laglera, L.M., van den Berg, C.M.G., 2009. Evidence for geochemical control of iron by humic substances in seawater. Limnol. Oceanogr. 54, 610-619. https://doi.org/10.4319/lo.2009.54.2.0610

Liu, X., Millero, F.J., 2002. The solubility of iron in seawater. Mar. Chem. 77, 43-54. https://doi.org/10.1016/S0304-4203(01)00074-3 
602

603

604

605

606

607

608

609

610

611

612

613

614

615

616

617

618

619

620

621

622

623

624

Lodovici, M., Guglielmi, F., Casalini, C., Meoni, M., Cheynier, V., Dolara, P., 2001. Antioxidant and radical scavenging properties in vitro of polyphenolic extracts from red wine. Eur. J. Nutr. 40, 74-77.

López, A., Rico, M., Santana-Casiano, J.M., González, A.G., González-Dávila, M., 2015. Phenolic profile of Dunaliella tertiolecta growing under high levels of copper and iron. Environ. Sci. Pollut. Res. 22, 14820-14828. https://doi.org/10.1007/s11356$015-4717-y$

Luther, G.W., Rozan, T.F., Witter, a, Lewis, B., 2001. Metal-organic complexation in the marine environment. Geochem. Trans. 2, 65. https://doi.org/10.1186/1467-4866$2-65$

Luther, G.W., Wu, J., Johnson, K.S., Gordon, R.M., Coale, K.H., Luther, G.W., Wu, J., Johnson, K.S., Gordon, R.M., Coale, K.H., 1997. What controls dissolved iron concentrations in the world ocean? - a comment. Mar. Chem. 57, 173-179. https://doi.org/10.1016/S0304-4203(97)00046-7

Maldonado, M.T., Price, N.M., 1999. Utilization of iron bound to strong organic ligands by plankton communities in the subarctic Pacific Ocean. Deep. Res. Part II Top. Stud. Oceanogr. 46, 2447-2473.

Martin, J.H., Gordon, M., Fitzwater, S.E., 1991. The case for iron. Limnol. Oceanogr. 36, 1793-1802. https://doi.org/10.4319/1o.1991.36.8.1793

Millero, F. J., 1986. The pH of estuarine waters. Limnol. Oceanogr. 31(4), 839-847.

Mira, L., Fernandez, M.T., Santos, M., Rocha, R., Florêncio, M.H., Jennings, K.R., 2002. Interactions of flavonoids with iron and copper ions: A mechanism for their antioxidant activity. Free Radic. Res. 36, 1199-1208. 
626

627

628

629

630

631

632

633

634

635

636

637

638

639

640

641

642

643

644

645

646

647

Moran, J.F., Klucas, R. V., Grayer, R.J., Abian, J., Becana, M., 1997. Complexes of iron with phenolic compounds from soybean nodules and other legume tissues: Prooxidant and antioxidant properties. Free Radic. Biol. Med. 22, 861-870. https://doi.org/10.1016/S0891-5849(96)00426-1

Morel, F.M.M., Price, N.M., 2003. The biogeochemical cycles of trace metals in the oceans. Science. 300(5621), 944-947. https://doi.org/10.1126/science.1083545

Morel, F. M., Kustka, A. B., Shaked, Y., 2008. The role of unchelated Fe in the iron nutrition of phytoplankton. Limnol. Oceanogr. 53(1), 400-404.

Norman, L., Worms, I.A.M., Angles, E., Bowie, A.R., Nichols, C.M., Ninh Pham, A., Slaveykova, V.I., Townsend, A.T., David Waite, T., Hassler, C.S., 2015. The role of bacterial and algal exopolymeric substances in iron chemistry. Mar. Chem. 173, 148-161. https://doi.org/10.1016/j.marchem.2015.03.015

Omanović, D., Garnier, C., Pižeta, I., 2014. ProMCC: An all-in-one tool for trace metal complexation $\quad$ studies. Mar. Chem. 173, 25-39. https://doi.org/10.1016/j.marchem.2014.10.011

Pižeta, I., Sander, S. G., Hudson, R. J. M., Omanović, D., Baars, O., Barbeau, K. A., Buck, K.N., Bundy, R.M., Carrasco, G., Croot, P.L., Garnier, C., Gerringa, L.J.A., Gledhill, M., Hirose, K., Kondo, Y., Laglera, L.M., Nuester, J., Rijkenberg, M.J.A., Takeda, S., Twining, B.S., Wells, M., 2015. Interpretation of complexometric titration data: An intercomparison of methods for estimating models of trace metal complexation by natural organic ligands. Mar. Chem. 173, 3-24.

Poorvin, L., Sander, S.G., Velasquez, I., Ibisanmi, E., LeCleir, G.R., Wilhelm, S.W., 

2011. A comparison of Fe bioavailability and binding of a catecholate siderophore with virus-mediated lysates from the marine bacterium Vibrio alginolyticus $\mathrm{PWH} 3 \mathrm{a}$. J. Exp. Mar. Bio. Ecol. 399, 43-47. https://doi.org/10.1016/j.jembe.2011.01.016

Powell, H. K. J., Taylor, M. C., 1982. Interactions of iron (II) and iron (III) with gallic acid and its homologues: a potentiometric and spectrophotometric study. Australian Journal of Chemistry, 35(4), 739-756.

Raspor, B., Nürnberg, H.W., Valenta, P., Branica, M., 1980. Kinetics and mechanism of trace metal chelation in sea water. J. Electroanal. Chem. 115, 293-308. https://doi.org/10.1016/S0022-0728(80)80333-0

Re, R., Pellegrini, N., Proteggente, A., Pannala, A., Yang, M., Rice-Evans, C., 1999. Antioxidant activity applying an improved ABTS radical cation decolorization assay. Free Radic. Biol. Med. 26, 1231-1237.

Rico, M., López, A., Santana-Casiano, J.M., González, A.G., González-Dávila, M., 2013. Variability of the phenolic profile in the diatom Phaeodactylum tricornutum growing under copper and iron stress. Limnol. Oceanogr. 58(1), 144-152. https://doi.org/10.4319/lo.2013.58.1.0144

Rue, E.E.L., Bruland, K.K.W., 1995. Complexation of iron(III) by natural organic ligands in the Central North Pacific as determined by a new competitive ligand equilibration/adsorptive cathodic stripping. Mar. Chem. 50, 117-138. https://doi.org/10.1016/0304-4203(95)00031-L

Sander, S. G., Hunter, K. A., Harms, H., and Wells, M., 2011. Numerical approach to speciation and estimation of parameters used in modeling trace metal bioavailability. Environ. Sci. Technol. 45(15), 6388-6395. 
671 Santana-Casiano, J., González-Dávila, M., González, A.G., Millero, F., 2010. Fe(III)

672

673

674

675

676

677

678

679

680

681

682

683

684

685

686

687

688

689

690

691

692

693 reduction in the presence of catechol in seawater. Aquat. Geochemistry 16, 467-482. https://doi.org/10.1007/s10498-009-9088-x

Santana-Casiano, J.M., González-Dávila, M., González, A.G., Rico, M., López, A., Martel, A., 2014. Characterization of phenolic exudates from Phaeodactylum tricornutum and their effects on the chemistry of $\mathrm{Fe}(\mathrm{II})-\mathrm{Fe}(\mathrm{III})$. Mar. Chem. 158, 10-16. https://doi.org/10.1016/j.marchem.2013.11.001

Sato, M., Takeda, S., Furuya, K., 2007. Iron regeneration and organic iron(III)-binding ligand production during in situ zooplankton grazing experiment. Mar. Chem. 106, 471-488. https://doi.org/10.1016/j.marchem.2007.05.001

Shaked, Y., Lis, H., 2012. Disassembling iron availability to phytoplankton. Frontiers in Microbiology, 3, 123.

Sroka, Z., Cisowski, W., 2003. Hydrogen peroxide scavenging, antioxidant and antiradical activity of some phenolic acids. Food Chem. Toxicol. 41, 753-758.

Stockdale, A., Tipping, E., Lofts, S., Mortimer, R.J.G., 2016. Effect of ocean acidification on organic and inorganic speciation of trace metals. Environ. Sci. Technol. 50, 1906-1913. https://doi.org/10.1021/acs.est.5b05624

Strlič, M., Radovič, T., Kolar, J., Pihlar, B., 2002. Anti-and prooxidative properties of gallic acid in fenton-type systems. Journal of Agricultural and Food Chemistry, 50(22), 6313-6317.

Sunda, W., Huntsman, S., 2003. Effect of pH, light, and temperature on Fe-EDTA chelation and Fe hydrolysis in seawater. Mar. Chem. 84, 35-47.

van den Berg, C.M.G., Kramer, J.R., 1979. Determination of complexing capacities of 

ligands in natural waters and conditional stability constants of the copper complexes by means of manganese dioxide. Anal. Chim. Acta 106, 113-120. https://doi.org/10.1016/S0003-2670(01)83711-9

Vasconcelos, M.T.S.D., Leal, M.F.C., van den Berg, C.M.G., 2002. Influence of the nature of the exudates released by different marine algae on the growth, trace metal uptake and exudation of Emiliania huxleyi in natural seawater. Mar. Chem. 77, 187210. https://doi.org/10.1016/S0304-4203(01)00087-1

Witter, A.E., Hutchins, D.A., Butler, A., Luther, G.W., 2000. Determination of conditional stability constants and kinetic constants for strong model Fe-binding ligands in seawater. Mar. Chem. 69, 1-17. https://doi.org/10.1016/S03044203(99)00087-0

Witter, A.E., Luther, G.W., 1998. Variation in Fe-organic complexation with depth in the Northwestern Atlantic Ocean as determined using a kinetic approach. Mar.Chem. 62, 241-258. https://doi.org/10.1016/S0304-4203(98)00044-9

Wu, J.F., Luther, G.W., 1995. Complexation of Fe(III) by natural organic-ligands in the Northwest Atlantic-Ocean by a competitive ligand equilibration method and kinetic approach. Mar. Chem. 50, 159-177.

\section{Acknowledgements}

This work was funded by "Laboratoire d'Excellence" LabexMER (ANR-10-LABX-19) and co-funded by a grant from the French Government under the program "Investissements d'Avenir", the Projects EACFe (CTM2014-52342-P) and ATOPFe 
716 (CTM2017-83476-P) given by the Ministerio de Economía y Competitividad from Spain

717 and the Postdoctoral program from the Universidad de Las Palmas de Gran Canaria. 
Table 1. Formation and dissociation constants, conditional stability constant and half-life time determined using the kinetic method. The initial concentration of dFe $=10.36 \mathrm{nM}$ and the initial concentration of studied ligand was $5 \mathrm{nM}$.

\begin{tabular}{|c|c|c|c|c|c|c|}
\hline $\begin{array}{l}\text { Studied } \\
\text { ligand }\end{array}$ & $\begin{array}{l}k_{\mathrm{f}} \times 10^{5} \\
\left(\mathrm{M}^{-1} \mathrm{~s}^{-1}\right)\end{array}$ & $\begin{array}{c}k_{\mathrm{d}} \times 10^{-4} \\
\left(\mathrm{~s}^{-1}\right)\end{array}$ & $\log K_{\mathrm{Fe}^{\prime} \mathrm{L}}^{\prime}$ & $\log K_{\mathrm{Fe} 3+\mathrm{L}}$ & $\begin{array}{c}\mathrm{Fe}^{\prime} \\
\mathbf{t}_{1 / 2}(\mathrm{~min})\end{array}$ & $\begin{array}{c}\mathrm{Fe}^{3+} \\
\mathbf{t}_{1 / 2}(\text { years })\end{array}$ \\
\hline$( \pm$ )-Catechin & $4.2 \pm 1.8$ & $2.43 \pm 0.03$ & $9.2 \pm 0.1$ & 19.20 & 20.6 & 0.54 \\
\hline Sinapic acid & $3.2 \pm 0.7$ & $4.4 \pm 0.3$ & $8.86 \pm 0.04$ & 18.86 & 11.3 & 0.23 \\
\hline Gallic acid & $3.1 \pm 0.4$ & $3.2 \pm 0.1$ & $9.01 \pm 0.02$ & 19.01 & 15.9 & 0.32 \\
\hline
\end{tabular}


Table 2. Concentration of studied ligand added and recovered after a titration, conditional stability constant determined using DP-CSV and calculated applying the ProMCC code. Errors represent the standard deviation from three replicates.

\begin{tabular}{|c|c|c|c|c|c|}
\hline $\begin{array}{l}\text { Studied } \\
\text { ligand }\end{array}$ & $\begin{array}{c}{[\mathrm{L}] \text { added }} \\
(\mathbf{n M})\end{array}$ & $\begin{array}{c}{[L]_{\text {recovered }}} \\
(\mathbf{n M})\end{array}$ & $K_{F e L}^{\prime} \times 10^{9}$ & $\log K_{F e L}^{\prime}$ & $\log _{F e^{3+} L}^{\prime}$ \\
\hline$( \pm)$-Catechin & 5.7 & $1.6 \pm 0.2$ & 2.0 & $9.3 \pm 0.1$ & 19.3 \\
\hline$( \pm)$-Catechin & 11.8 & $3.6 \pm 0.5$ & 1.3 & $9.1 \pm 0.2$ & 19.1 \\
\hline Sinapic acid & 5.0 & $3.6 \pm 0.8$ & 0.4 & $8.6 \pm 0.2$ & 18.6 \\
\hline Sinapic acid & 9.9 & $6.5 \pm 0.7$ & 0.4 & $8.6 \pm 0.1$ & 18.6 \\
\hline Gallic acid & 2.0 & $5.5 \pm 0.3$ & 0.6 & $8.8 \pm 0.2$ & 18.8 \\
\hline Gallic acid & 5.0 & $14 \pm 2$ & 3.2 & $9.5 \pm 0.1$ & 19.5 \\
\hline
\end{tabular}




\section{LIST OF FIGURES}

Figure 1. Chemical structure of ( \pm )-catechin (A), sinapic acid (B) and gallic acid (C)

Figure 2. Example of titration of natural seawater (dots) and 4 hours UV-irradiated seawater (squares).

Figure 3. Kinetic of formation of Fe complexes with ( \pm ) - catechin (A), sinapic acid (B) and gallic acid (C), where the concentration of $\mathrm{dFe}$ is expressed as labile Fe because of $\mathrm{Fe}(\mathrm{TAC})_{2}$ complex was measured after 20 sec. Kinetic of dissociation of $( \pm)$ - catechin (D), sinapic acid (E) and gallic acid (F), where the concentration of dFe is expressed as TAC labile Fe due to the interaction between TAC and the studied ligands. Dashed lines correspond to the fitting of the results. All the experiments were carried out in triplicate in UV-irradiated seawater. The initial concentration of dFe was $10.36 \mathrm{nM}$. X-axis are in different scale for each polyphenol due to their reaction time.

Figure 4. Percentage of Fe(II) reduced from Fe(III) in UV-seawater at pH 8.0 and $\mathrm{T}=25^{\circ} \mathrm{C}$ in the presence of $( \pm)-$ catechin, sinapic acid and gallic acid. 


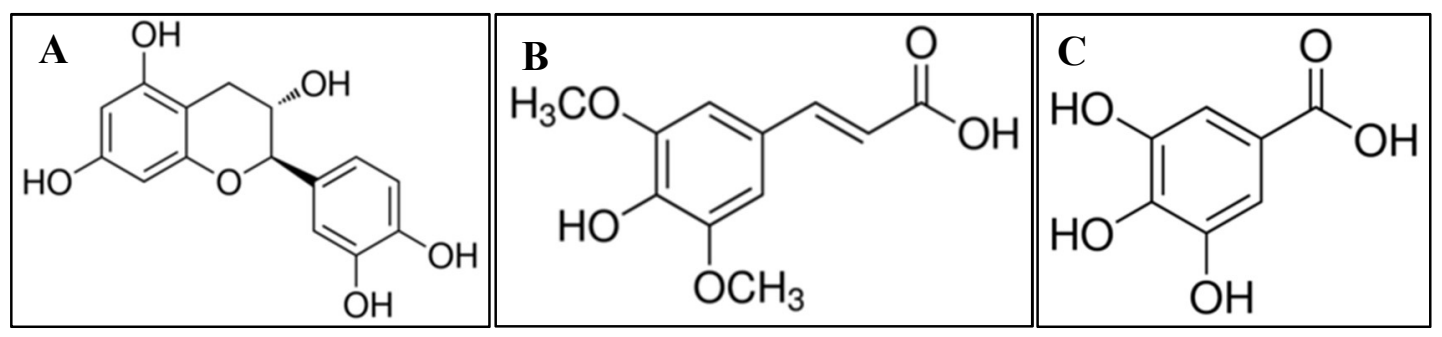

Figure 1. Chemical structure of ( \pm )-catechin (A), sinapic acid (B) and gallic acid (C). 


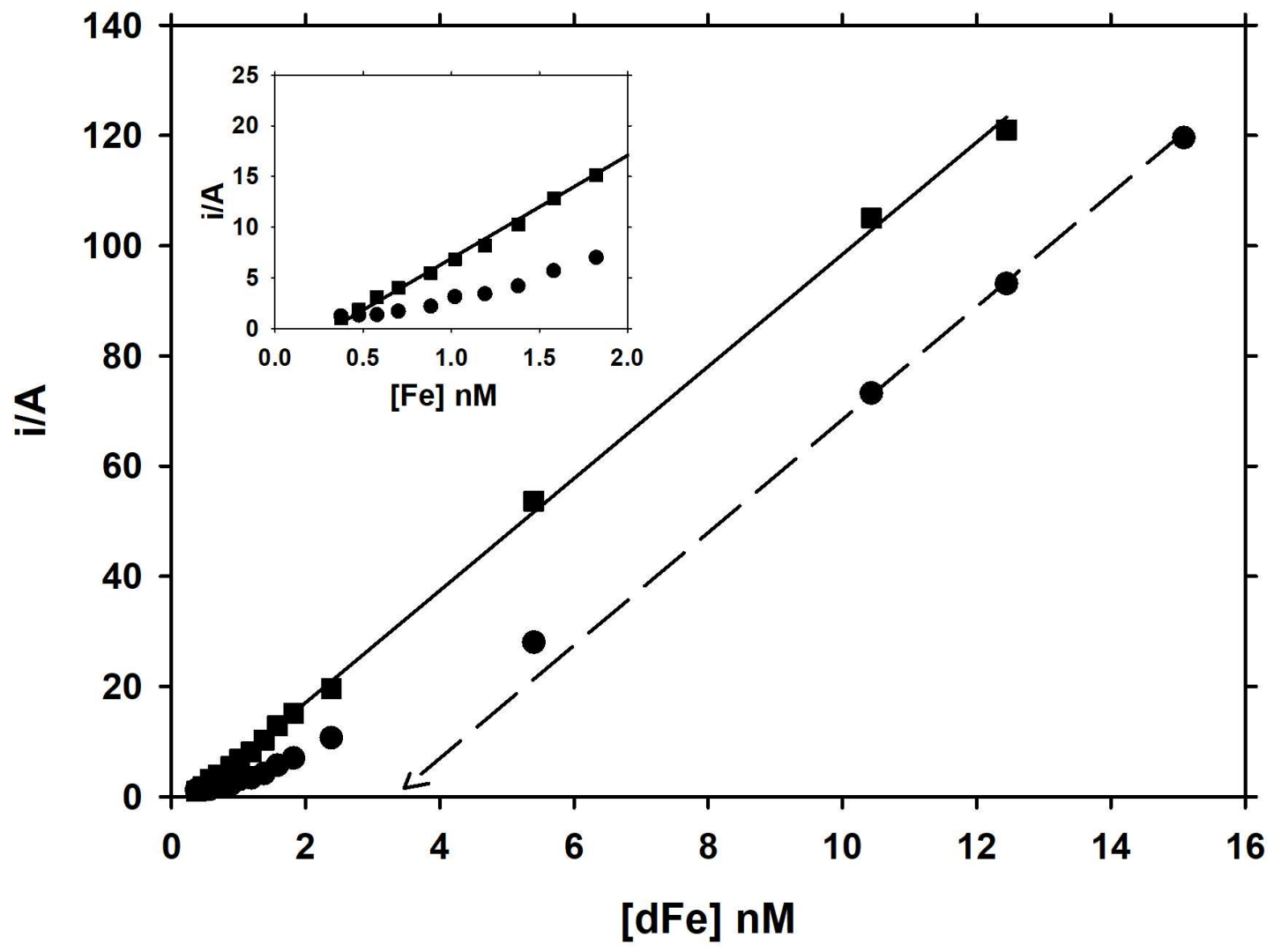

Figure 2. Example of titration of natural seawater (dots) and 4 hours UV-irradiated seawater (squares). 

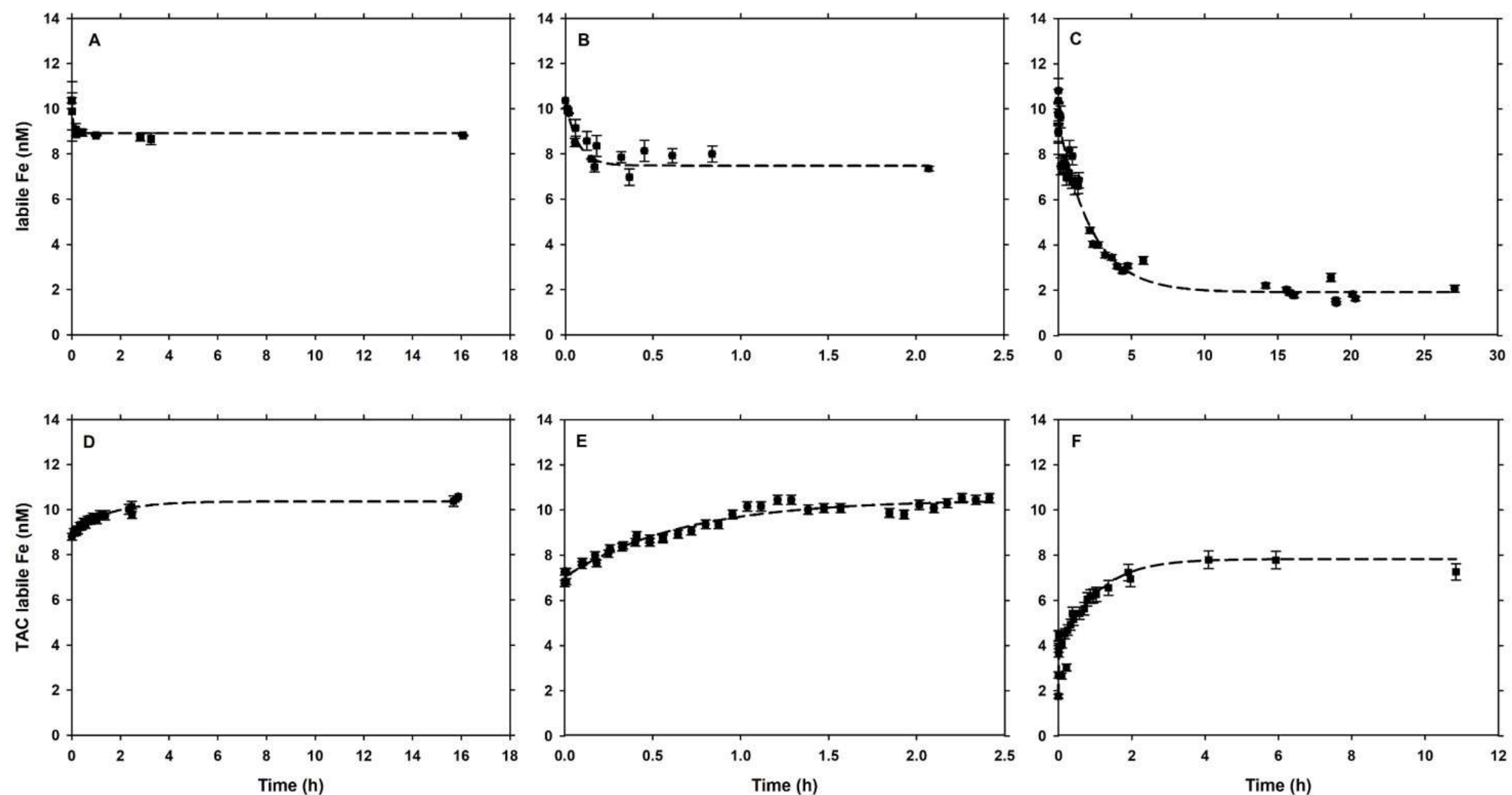

Figure 3. Kinetic of formation of Fe complexes with ( \pm ) - catechin (A), sinapic acid (B) and gallic acid (C), where the concentration of dFe is expressed as labile Fe because of Fe(TAC)2 complex was measured after 20 sec. Kinetic of dissociation of ( \pm ) - catechin (D), sinapic acid (E) 
and gallic acid (F), where the concentration of dFe is expressed as TAC labile Fe due to the interaction between TAC and the studied ligands.

Dashed lines correspond to the fitting of the results. All the experiments were carried out in triplicate in UV-irradiated seawater. The initial concentration of $\mathrm{dFe}$ was $10.36 \mathrm{nM}$. X-axis are in different scale for each polyphenol due to their reaction time. 


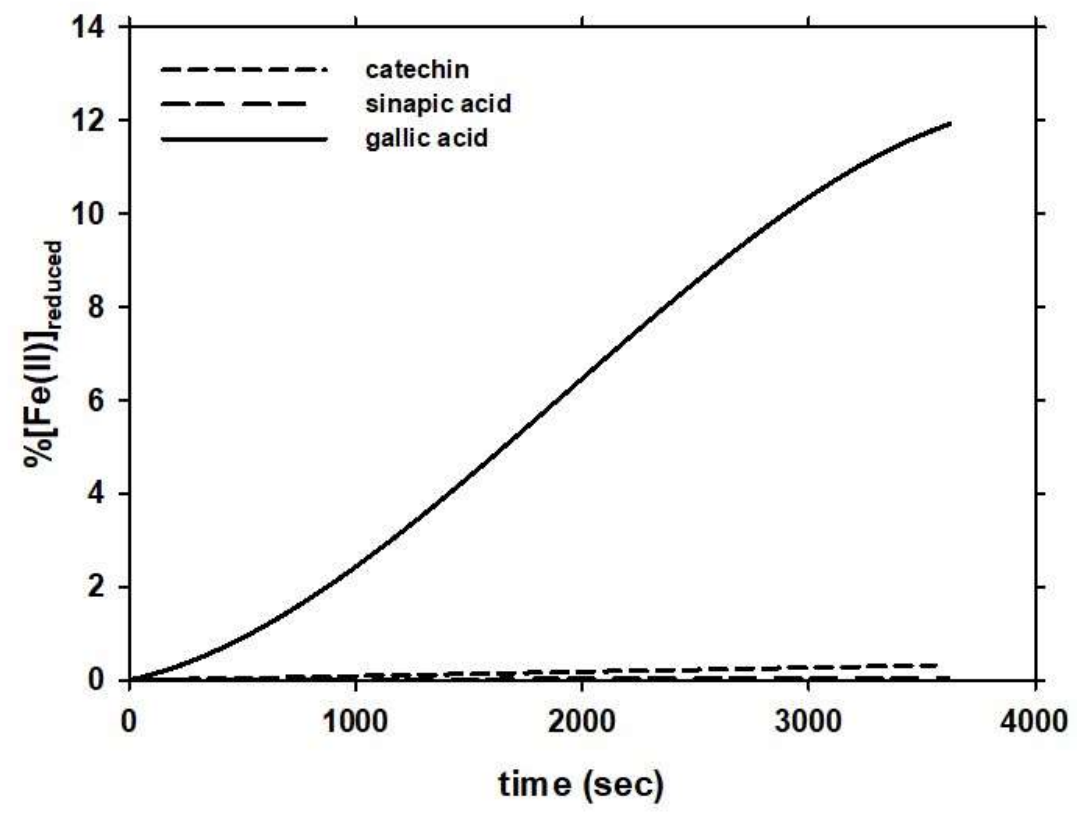

Figure 4. Percentage of $\mathrm{Fe}(\mathrm{II})$ reduced from $\mathrm{Fe}(\mathrm{III})$ in $\mathrm{UV}$-seawater at $\mathrm{pH} 8.0$ and $\mathrm{T}=25^{\circ} \mathrm{C}$ in the presence of $( \pm)$ - catechin, sinapic acid and gallic acid. 